\title{
PELATIHAN PENGELOLAAN KEUANGAN RUMAH TANGGA
}

\author{
Nujmatul Laily ${ }^{1}$, Dian Syariati², Hanjar Ikrima Nanda \\ 1.2.3 Jurusan Akuntansi, Fakultas Ekonomi, Universitas Negeri Malang \\ Email: nujmatul.laily.fe@um.ac.id ${ }^{1}$, dian.syariati.fe@um.ac.id², hanjar.ikrima.fe@um.ac.id \\ Submitted: 21 November Accepted: 23 April 2021 Published: 30 April 2021
}

\begin{abstract}
Abstrak Keuangan rumah tangga menjadi salah satu hal penting yang patut diperhatikan, terutama oleh bendahara keluarga. Hasil LGD di tahun 2019 menunjukkan kesulitan ibu, sebagai bendahara keluarga, dalam mengelola keuangan di keluarganya, sehingga seringkali seadanya. Pemasukan dan pengeluaran pun tidak seimbang, dan akhirnya tidak sedikit yang memicu konflik di akhir bulan. Lokakarya pengelolaan keuangan keluarga sudah selayaknya dilakukan untuk mengedukasi para bendahara keluarga agar bijak mengelola keuangan di rumahnya sendiri. Lokakarya hendaknya dikemas sesuai dengan pendidikan orang dewasa, yaitu sesuai kebutuhan, dan terdapat praktik pengelolaan keuangan. Selain itu untuk mengetahui keberhasilan kegiatan dan juga evaluasi, maka pendampingan akan dilakukan. Pendampingan menjadi ajang diskusi dalam memecahkan masalah yang dihadapi, ketika mengelola keuangan, dan juga menjadi media untuk memperkuat motivasi. Hasil pelatihan dan pendampingan menunjukkan bahwa peserta sangat antusias dengan tema yang diangkat serta mayoritas peserta mengaku sangat terbantu dengan sharing ilmu melalui pelatihan ini.
\end{abstract}

Kata Kunci: Keuangan Rumah Tangga, Bendahara Keluarga, Anggaran 


\section{PENDAHULUAN}

Pemahaman tentang keuangan sangat penting bagi seseorang untuk mewujudkan kesejahteraan dalam hal keuangan (Younas \& Farooq, 2019). Literasi keuangan menjadi salah satu indikator kemampuan seseorang dalam mengambil keputusan keuangan (Lusardi, 2019). Namun, hasil survey dari OECD (Organisation for Economic Co-operation and Development) menemukan bahwa literasi keuangan masyarakat masih sangat rendah di negara-negara anggota APEC khususnya di Indonesia (OECD, 2019). Financial literacy berhubungan dengan kemampuan seseorang dalam mengelola keuangan (Halilovic et al., 2019) tanpa terkecuali seorang ibu rumah tangga.

Keuangan rumah tangga menjadi salah satu hal penting yang menopang kesejahteraan individu di dalamnya. Seorang istri (Ibu) memiliki peranan yang signifikan dalam mengatur penghasilan dalam suatu keluarga. Penghasilan kita perlu dikelola agar dapat memenuhi kebutuhan saat ini dan juga kebutuhan di masa depan. Kebutuhan saat ini terdiri atas pengeluaran- pengeluaran yang dikeluarkan saat ini. Contoh kebutuhan saat ini antara lain biaya dapur, biaya cicilan motor, biaya pulsa telepon genggam. Sedangkan kebutuhan di masa depan terdiri atas pengeluaranpengeluaran dikeluarkan di masa mendatang. Contoh kebutuhan di masa depan antara lain biaya pendidikan anak hingga tamat sekolah, biaya naik haji, dan biaya pernikahan anak (OJK, 2019). Hasil Leadership Group Discussion (LGD) dengan ibu-ibu di kota Malang, menunjukkan adalah kesulitan dalam mengelola keuangan rumah tangga. Kurangnya kemampuan dalam mengelola pemasukan dan pengeluaran seringkali memicu konflik keluarga. Ibu yang biasanya menjadi bendahara keluarga pun menjadi sorotan ketika kondisi keuangan menipis. Sistem amplop yang dilakukan oleh salah satu Ibu di Kota Malang, terkadang efektif dalam mengerem pengeluaran, hanya jika pemasukan mencukupi. Namun ketidakkonsistenan dalam mengerem kebutuhan tersier menyebabkan pengelolaan keuangan apa adanya, sebagaimana yang diungkapkan Indriyani (2019) bahwa pengelolaan keuangan keluarga seringkali berjalan seadanya dan tanpa rencana.

Pengelolaan keuangan yang baik sebenarnya bisa mengurangi risiko 
konflik yang terjadi dalam rumah tangga. Berapapun pemasukannya, minimal harus seimbang dengan pengeluaran. Berdasarkan hasil LGD, ibu-ibu di Kota Malang biasanya tidak konsisten dalam mengelola keuangannya. Rencana yang telah disusun biasanya berlalu begitu saja dikarenakan adanya pengeluaran dadakan, yang terlihat penting, tanpa diimbangi dengan perencanaan pemasukan yang mumpuni. Hasilnya tidak sedikit ibu-ibu yang sering pusing di akhir bulan, atau pada masa pembayaran kebutuhan dadakan, misalnya biaya rumah sakit, biaya sekolah, dan lain sebagainya.

Fenomena ini tidak hanya terjadi pada ibu rumah tangga yang tidak memiliki penghasilan, namun mereka yang berpenghasilan-pun seringkali mengalami hal yang sama karena terlena dengan hal yang belum direncanakan. Tidak hanya mereka yang memiliki latar belakang di bidang ekonomi atau keuangan, mereka yang ber-background akuntan pun mengakui masih sulit menata keuangan, dan seringkali minus. Gali lubang tutup lubang pun menjadi hal yang lumrah dilakukan. Permasalahan yang telah diuraikan di atas harus segara mungkin diatasi sehingga penting sekali untuk dilaksanakan kegiatan pelatihan dan pendampingan pengelolaan keuangan rumah tangga.

\section{TINJAUAN PUSTAKA}

Strategi, teknik, dan instrumen dalam mengelola keuangan rumah tangga, yaitu:

\section{Penyadaran}

Penyadaran adalah penyadaran dalam lingkup rumah tangga. Negara sebagai pembuat kebijakan seperti aturan, subsidi, pendidikan, kesehatan dan keamanan. Rumah tangga : keluarga yang memberikan edukasi terkait pengelolaaan keuangan. Masyarakat : Lingkungan, budaya, pergaulan hubungan sosial

\section{Sasaran}

Sasaran disini ada 5 kategori, sasaran dalam mengelola keuangan tentu berbeda-beda
a. Pasangan baru yang baru menikah
b. Keluarga grow up (anak masih kecil)
c. Keluarga mature (anak yang sudah dewasa)
d. Pasangan lansia (anak mandiri)


3. Perencanaan dan Pengelolaan (Manage)

a. Perencanaan

Merencanakan: penerimaan - pengeluaran - SOP RT

b. Organizing ( Mengatur)

Menyusun berbagai tujuan rumah tangga

c. Staffing (Menata Pembagian Kerja)

Pembagian kerja di rumah misalnya siapa yang mengurus anak atau pekerjaan rumah lainnya

d. Coordinating (Komunikasi)

Membangun komunikasi yang intens

e. Controlling (Pengawasan)

Umpan balik kendala solusi

Jika semua itu terpenuhi maka akan tercapai goals Keluarga Sejahtera. Apa yang perlu direncanakan? Kita harus dapat mengklasifikasi pendapatan dan pengeluaran agar keuangan dalam rumah tangga dapat tertata. Ada empat pendapatan yaitu:

a. Income 1 (Pendapatan Utama) :Misal gaji pokok dari pekerjaan tetap

b. Income 2 ( Pendapatan Sampingan) : Pendapatan dari pekerjaan sampingan c. Cost 1 ( Pengeluaran Rutin)

: Belanja bulanan misalnya kebutuhan pokok, air, listrik dan sebagainya

d. Cost 2 (Pengeluaran Sekunder) : Membeli tas atau baju baru

Dengan melihat kelebihan dan kekuarangan pada tabel kuadran 1-4 Kuadran 1: Suami (Bekerja Tetap) dan Istri ( Bekerja Tetap)

Kuadaran 2 : Suami (Bekerja Tetap) dan Istri ( Tidak Bekerja)

Kuadran 3 : Suami (Tidak Bekerja) dan Istri (Bekerja Tetap)

Kuadran 4 Suami (Tidak Bekerja Tetap) dan Istri (Tidak Bekerja Tetap) misalnya: serabutan buruh bangunan, bisnis online, dan lain-lain. Oleh karena itu, Ada 2 Jenis Mama, yaitu (1) memutuskan untuk bekerja membantu suami dan (2) memutuskan berhenti bekerja demi keluarga ( mengurus anak, suami).

\subsection{Jenis Pengeluaran}

Ada dua jenis pengeluaran yang perlu diatur dalam pengelolaan keuangan rumah tangga, di antaranya:

1. Rutin (Primer)

Contoh: Keperluan dapur, listik,air, sewa atau cicilan rumah, 
pendidikan anak, transportasi

(bensin dan cicilan kendaraan), asuransi kesehatan.

\section{Sekunder}

Contoh: Orang tua/keluarga sakit, acara syukuran, alat dapur baru, mobil baru, rehab rumah, HP/laptop/tas baru.

Kita harus membuat porsi pengeluaran jangan sampai rumah tangga mempunyai hutang. Jika sudah berhutang cicilan rumah misalnya kita tidak perlu mempunyai hutang seperti cicilan tas baru, hp baru dan sebagainya. Pendapatan boleh naik, gaya hidup jangan. Jadi kita harus pandai-pandai menata keuangan kita. Bagaimana cara mengatur keuangan?

1. Memilih : kita harus memilihmilih pengeluaran dengan bijak mana yang harus diprioritaskan/dipenuhi terlebih dahulu seperti kebutuhan pokok

2. Mencatat : mencatat semua pengeluaran rutin maupun pengeluaran yang tidak terduga

3. Mengaokasikan mengalokasikan keuangan untuk item pengeluaran misal keperluan dapur, listrik, air, Indihome, dll
4. Merenung : kita perlu mengevaluasi pengeluaran kita selama ini apakah sudah sesuai dengan catatan kita atau belum

Kemudian apa itu staffing dalam rumah tangga? Dalam rumah tangga terdiri dari dua peran yaitu

1. Peran suami sebagai kepala ruumah tangga yang bekerja mencari nafkah kemudian dalam rumah jika ada pekerjaan rumah yang berifat berat, sang kepala rumah tangga yang mengatasinya.

2. Peran istri sebagai ibu rumah tangga yang bertanggung jawab menjaga rumah dan isinya, menjaga anak dan mengurus dapur serta kebersihan rumah.Pelatihan ini menggunakan mediatradisional dan berbasis teknologi.LCD digunakan pada saat pemberian materi, sehingga peserta memiliki gambaran materi dengan lebih jelas.

\section{METODE PENELITIAN}

Adapun metode yang digunakan untuk melaksanakan kegiatan pengabdian ini adalah sebagai berikut: 
a. Lokakarya

Pengelolaan

Keuangan Keluarga

Ibu atau bendahara keluarga yang ada di Kota Malang akan diberikan informasi terkait dengan teknik pengelolaan keuangan keluarga. Pada lokakarya ini, peserta juga diberikan praktik pengelolaan keuangan keluarga. Selanjutnya peserta dihimbau untuk menerapkan hasil lokakarya dalam mengelola keuangan keluarga.

b. Pendampingan

Pendampingan dilaksanakan sebulan setelah lokakarya dilakukan, untuk meninjau perubahan pengelolaan keuangan pasca peserta mengikuti lokakarya. Pendampingan juga dilakukan dalam bentuk diskusi, untuk memecahkan masalah pengelolaan keuangan keluarga secara bersama-sama.

c. Evaluasi

Evaluasi diadakan usai kegiatan lokakarya, dan juga pendampingan. Evaluasi bertujuan untuk mengetahui kepuasan peserta setelah mengikuti rangkaian kegiatan. Evaluasi diambil dalam bentuk angket dan wawancara. Pada tahap ini peserta juga diberikan motivasi untuk senantiasa memperbaiki pengelolaan keuangan di keluarganya.

Berdasarkan prioritas permasalahan yang dihadapi oleh mitra terkait minimnya pengetahuan serta keterampilan peserta dalam mengelola keuangan rumah tangga maka metode pendekatan yang akan digunakan untuk kegiatan pengabdian kepada masyarakat ini adalah memberikan pelatihan sekaligus pendampingan tentang pengelolaan keuangan rumah tangga serta pendampingan dalam menyusun anggaran keuangan rumah tangga.

\section{HASIL DAN PEMBAHASAN}

Kegiatan pengabdian kepada masyarakat ini dilaksanakan pada tanggal 25 Juli 2020. Terdapat perbedaan dalam pelaksanaan dan rencana kegiatan pengabdian. Dalam hal ini, kegiatan pengabdian yang semula direncanakan dalam bentuk pelatihan dan pendampingan berubah menjadi pelaksanaan webinar. Hal ini dilakukan untuk mengantisipasi persebaran covid 19 di kota Malang yang masih masuk 
zona merah (suryamalang.com, 11 Juli 2020). Tahapan kegiatan yang dilaksanakan dalam kegiatan pengabdian ini adalah sebagai berikut:

\section{Observasi}

Tim melaksanakan observasi awal untuk mengidentifikasi permasalahan serta menjajaki kemungkinan kerjasama dengan mitra. Kerjasama dilaksanakan dengan Ruang Belajar Aqil (RBA).

\section{Koordinasi dengan mitra dan} persiapan kegiatan

Tim mengidentifikasi peserta, merencanakan materi, merencanakan pelaksanaan kegiatan, serta mempersipkan kebutuhan pelaksanaan kegiatan Webinar Pelatihan dan Pendampingan "Kiat Sukses Mengelola Keuangan Rumah Tangga”. Webinar dilaksanakan dengan menggunakan media zoom melalui laman https://bit.ly/20200725Lokakar yaRBA.

Materi yang disampaikan dalam webinar terdiri dari:
1. Perilaku
Pengelolaan

Pendapatan dan Pengeluaran
Materi ini disampaikan oleh Bapak Atu Bagus Wiguna, SE., ME. Materi secara umum berisi tentang prinsip (keprilakuan) pengelolaan. Dalam hal ini, diperkenalkan 3 konsep. Pertama, kepuasan sama dengan budget. Kedua, kehidupan kerja yang seimbang. Ketiga, refleksi psikis tentang kepuasaan di mana setiap orang memiliki kepuasan dalam bentuk berbeda. Berkenaan dengan tiga hal ini dibutuhkan perencanaan dan pengelolaan keuangan yang dibahas dalam materi kedua.

2. Perencaaan dan Pengelolaan Keuangan Rumah Tangga. Materi ini disampaikan oleh Bapak Muhammad Ikbal, SE., MSA., CSRA., CSP. Materi secara umum membahas tentang tahapan perencanaan dan pengelolaan rumah tangga yang meliputi perencanaan pendapatan dan pengeluaran; mengatur anggaran rumah tangga, menata pembagian kerja, mengkomunikasikan anggaran kepada anggota 
rumah tangga, serta mengawasi pelaksanaan anggaran. Selain itu, materi ini membahas pula tentang tips mengatur keuangan runah tangga, yakni menganggarkan dengan cermat, mengalokasikan dana darurat, memasak sendiri, membatasi shopping, menerapkan hemat listrik, menghindari hutang, serta melakukan pekerjaan sampingan.

3. Kesan peserta pelatihan Berdasarkan angket yang disebarkan kepada peserta, mayoritas peserta mengaku pelatihan ini dapat memberikan pengetahuan serta keterampilan baru dalam mengelola keuangan rumah tangga khususnya di masa pandemi ini. Peserta juga berharap kegiatan semacam ini sering dilakukan karena sangat bermanfaat bagi masyarakat khususnya yang terdampak Covid-19.

\section{KESIMPULAN}

Kegiatan pelatihan pengelolaan keuangan rumah tangga ini dapat dikatakan berhasil karena melalui pelatihan ini peserta mengaku memperoleh pengetahuan baru tentang pengelolaan keuangan rumah tangga. Peserta menilai bahwa kegiatan ini sangat bermanfaat bagi mereka khususnya dimasa pandemi ini. Kegiatan pelatihan dan pendampingan ini sangat disambut baik oleh peserta sehingga kegiatan-kegiatan ini dapat ditindaklanjuti pada tahun-tahun berikutnya.

\section{UCAPAN TERIMAKASIH}

Ucapan terima kasih kepada Universitas Negeri Malang yang telah mendanai kegiatan pengabdian ini.

\section{DAFTAR PUSTKA}

Dewi, R. R. (2015). Model Proses Androgogi untuk Pembelajaran. Retrieved from Berbagi Pengetahuan: http://rinitarosalinda.blogspot.com /2015/04/model-proses-andragogiuntuk.html

Halilovic, S., Zaimovic, A., Berilo, A. A., \& Zaimovic, T. (2019). Financial Literacy Assessment in Bosnia and Herzegovina. Procedia Computer Science, 158, 836-843. https://doi.org/10.1016/j.procs.201 


\subsubsection{1}

Indriyani, W. 2019. Cerdas dan Bijak

Mengatur Keuangan Rumah

Tangga. Sidoarjo: CV. Embrio

Publisher

Lusardi, A. (2019). Financial literacy and the need for financial education: evidence and implications. Swiss Journal of Economics and Statistics, 155(1), $1-8$.

https://doi.org/10.1186/s41937019-0027-5

Tamat, T. (1985). Dari Pedagogik ke Androgogik. Jakarta: Pustaka Dian. Younas, W., \& Farooq, M. (2019). Impact of Self-Control, Financial Literacy and Financial Behavior on Financial Well-Being. The Journal of Social Sciences Research, 5(51), 211-218. https://doi.org/10.32861/jssr.5 1.211 .218 